Methodology article

\title{
Immunoaffinity purification and characterization of mitochondrial membrane-bound D-3-hydroxybutyrate dehydrogenase from
} Jaculus orientalis

\author{
Driss Mountassif ${ }^{1,2}$, Pierre Andreoletti ${ }^{1}$, Zakaria El Kebbaj², \\ Adnane Moutaouakkil ${ }^{3,4}$, Mustapha Cherkaoui-Malki ${ }^{1}$, Norbert Latruffe*1 \\ and M'hammed Saïd El Kebbaj²
}

Address: ${ }^{1}$ INSERM U866 (Institut National de la Santé et de la Recherche Médicale), Université de Bourgogne, LBMC (Biochimie Métabolique et Nutritionnelle), Faculté des Sciences, 6 Bd Gabriel, 21000 Dijon cedex, France, ${ }^{2}$ Laboratoire de Biochimie et Biologie Moléculaire, Université Hassan II - Aïn Chock, Faculté des Sciences Aïn Chock, km 8 route d'El Jadida BP. 5366, Mâarif, Casablanca, Morocco, ${ }^{3}$ Laboratoire de Physiologie et Génétique Moléculaire, Université Hassan II - Aïn Chock, Faculté des Sciences Aïn Chock, km 8 route d'El Jadida BP. 5366, Mâarif, Casablanca, Morocco and ${ }^{4}$ Unité de Radio-Immuno-Analyse, Département des Applications aux Sciences du Vivant, CNESTEN (Centre National de l'Energie, des Sciences et des Techniques Nucléaires), BP 1382 RP, 10001 Rabat, Morocco

Email: Driss Mountassif - drissmountassif@yahoo.fr; Pierre Andreoletti - pierre.andreoletti@u-bourgogne.fr; Zakaria El Kebbaj - zelkebbaj@yahoo.fr; Adnane Moutaouakkil - moutaouakkil@cnesten.org.ma; Mustapha Cherkaoui-Malki - malki@u-bourgogne.fr; Norbert Latruffe* - latruffe@u-bourgogne.fr; M'hammed Saïd El Kebbaj - mselkebbaj@hotmail.com

* Corresponding author

Published: 30 September 2008

BMC Biochemistry 2008, 9:26 doi:10.1186/147|-2091-9-26
Received: 27 March 2008

Accepted: 30 September 2008

This article is available from: http://www.biomedcentral.com/I47I-209I/9/26

(C) 2008 Mountassif et al; licensee BioMed Central Ltd.

This is an Open Access article distributed under the terms of the Creative Commons Attribution License (http://creativecommons.org/licenses/by/2.0), which permits unrestricted use, distribution, and reproduction in any medium, provided the original work is properly cited.

\begin{abstract}
Background: The interconversion of two important energy metabolites, 3-hydroxybutyrate and acetoacetate (the major ketone bodies), is catalyzed by D-3-hydroxybutyrate dehydrogenase $\left(\mathrm{BDH}^{\prime}\right.$ : EC I.I.I.30), a NAD+-dependent enzyme. The eukaryotic enzyme is bound to the mitochondrial inner membrane and harbors a unique lecithin-dependent activity. Here, we report an advanced purification method of the mammalian BDH applied to the liver enzyme from jerboa (Jaculus orientalis), a hibernating rodent adapted to extreme diet and environmental conditions.

Results: Purifying BDH from jerboa liver overcomes its low specific activity in mitochondria for further biochemical characterization of the enzyme. This new procedure is based on the use of polyclonal antibodies raised against BDH from bacterial Pseudomonas aeruginosa. This study improves the procedure for purification of both soluble microbial and mammalian membranebound $\mathrm{BDH}$. Even though the Jaculus orientalis genome has not yet been sequenced, for the first time a D-3-hydroxybutyrate dehydrogenase cDNA from jerboa was cloned and sequenced.

Conclusion: This study applies immunoaffinity chromatography to purify BDH, the membranebound and lipid-dependent enzyme, as a $3 / \mathrm{kDa}$ single polypeptide chain. In addition, bacterial BDH isolation was achieved in a two-step purification procedure, improving the knowledge of an enzyme involved in the lipid metabolism of a unique hibernating mammal. Sequence alignment revealed conserved putative amino acids for possible $\mathrm{NAD}^{+}$interaction.
\end{abstract}




\section{Background}

The $\mathrm{NAD}^{+}$-dependent $\mathrm{D}$-3-hydroxybutyrate dehydrogenase (BDH: EC 1.1.1.30), which has been studied by our group for several years [1-9], plays a key role in redox balance and energy metabolism since it reversibly converts 3hydroxybutyrate into acetoacetate (the two major ketone bodies largely produced under high lipolysis, diabetes, or fasting). In eukaryotic cells, $\mathrm{BDH}$ is a mitochondrial inner membrane-bound enzyme $[1,10,11]$ and its active site is located on the matrix side $[2,12]$. $\mathrm{BDH}$ is coded by a nuclear gene and is synthesized in free cytosolic polysomes as a precursor that is posttranslationally imported into mitochondria and then processed at its $\mathrm{N}$-terminus presequence $[4,13]$. A very unique property, the catalytic activity of the enzyme is lecithin-dependent $[14,15]$. The purified $\mathrm{BDH}$ is nonactive in absence of lipids but can insert spontaneously and unidirectionally into liposomalphospholipid vesicles or into purified membranes and then become catalytically active [12]. It has previously been proposed that specific activation of BDH by phosphatidylcholine (PC)-containing liposomes involves an allosteric mechanism [16] in which PC enhances coenzyme-binding [17]. As reported by Williamson et al. [18], according to the equilibrium constant, in the presence of $\mathrm{NADH}$, the hepatic BDH transforms acetoacetate into D3-hydroxybutyrate, which is then transported through the blood stream to peripheral tissues, i.e., brain, heart, kidney, etc. In extrahepatic tissues, BDH catalyzes the reverse reaction where acetoacetate is used, after its conversion to acetyl-CoA, in ATP production. On the other hand, acetoacetyl-CoA can be used for fatty acid synthesis. A catalytic mechanism involving cystenyl and histidyl residues of the BDH active site for the interconversion of $\mathrm{D}-3$ hydroxybutyrate and acetoacetate in both liver and peripheral tissues has been previously proposed by our group [7].

In striking contrast to mammalian $\mathrm{BDH}$, the bacterial $\mathrm{BDH}$ is a cytosolic soluble enzyme and does not require phospholipids for its activity [19]. Indeed, the role of $\mathrm{BDH}$ in many bacteria is to produce $\mathrm{D}$-3-hydroxybutyrate, which is a substrate for the synthesis of poly -3-hydroxybutyrate (PHB) as intracellular carbon energy storage [20].

Elsewhere, our group has long been interested in the lipid metabolism of an intriguing mammalian species: the jerboa (Jaculus orientalis) $[9,21]$. The jerboa is a nocturnal herbivorous rodent living mainly in Morocco's subdesert highland. It is an appropriate organism to study metabolic regulation because of its remarkable tolerance to heat, cold, dryness and scarce diet. This animal is a true hibernator [22], developing a seasonal obesity by accumulating fat during the prehibernation period. This fat is used during the hibernation period, together with carbo- hydrates, to produce energy via the formation of D-3hydroxybutyrate by BDH [21].

To further characterize BDH from jerboa, it appeared necessary to overcome its low specific activity in mitochondria by purifying the enzyme from liver of the jerboa by establishing a new and original purification technique. Indeed, while bacterial $\mathrm{BDH}$ can be easily purified with the classical method for soluble enzymes $[23,24]$, enormous effort has gone into purifying the mitochondrial membrane-bound BDH from mammals, mostly from bovine heart $[1,6,25-34]$, rat liver $[1,6,31-33]$, rat brain [34], recombinant rat liver enzyme expressed in Escherichia coli [35], and Camelus liver [8]. Typically, after membrane disruption by detergent (cholate or Triton X100 ) or by phospholipase A2-generated lysophospholipids, the purification procedures were based on combined chromatographies (adsorption, dihydroxyapatite, ionic exchange, hydrophobic, $\mathrm{NAD}^{+}$or $\mathrm{NAD}^{+}$-related affinity, and often controlled pore glass beads). Unfortunately, these methods were difficult to adapt to other sources. Until now, no-one has proposed an immunoaffinity purification method. Here, we report the development of an antibody-antigen procedure based on the existence of conserved epitopes between bacterial and mammalian $\mathrm{BDH}$. Indeed, BDH from Jaculus orientalis was purified using polyclonal antibodies raised against a prokaryotic BDH purified from the bacterium Pseudomonas aeruginosa. After solubilization of mitochondrial membranes using Triton X-100, purification of jerboa liver BDH was processed using ammonium sulfate precipitation and phenylSepharose and Sepharose-Blue chromatographies. Final purification was achieved by immunochromatography, providing a $31 \mathrm{kDa}$ single polypeptide chain. Moreover, even though the genome of Jaculus orientalis has not been sequenced, a D-3-hydroxybutyrate dehydrogenase cDNA from jerboa was cloned and sequenced for the first time. Sequence alignment revealed conserved putative essential amino acids for $\mathrm{NAD}^{+}$interaction. This study applied immunoaffinity chromatography to purify $\mathrm{BDH}$, a membrane-bound and lipid-dependent enzyme. In addition, bacterial BDH was isolated in a two-step purification procedure, providing better knowledge of a lipid metabolism enzyme in a unique hibernating mammalian species.

\section{Results \\ - Purification of soluble BDH from Pseudomonas aeruginosa}

BDH was purified to electrophoretic homogeneity from $P$. aeruginosa extract in a two-step ammonium sulfate fractionation $(27-42 \%)$ procedure, followed by Blue Sepharose CL-6B chromatography.

In a typical experiment, a total amount of $4600 \mathrm{mg}$ of protein, corresponding to 1012 units of $\mathrm{BDH}$, was obtained 
from crude extract of $P$. aeruginosa. After ammonium sulfate fractionation, the concentrated enzyme solution was applied to a Blue Sepharose CL-6B column. A specific activity of $11.2 \mathrm{U} / \mathrm{mg}$ of protein was obtained for the purified enzyme, with a yield of $6.6 \%$ and a purification factor of 50 (not shown).

The SDS-PAGE analysis of the different fractions obtained during this purification shows only one protein band at $29 \mathrm{kDa}$ in the final enzyme preparation [Additional file $1]$.

Using purified $\mathrm{BDH}$ as the immunogen, we produced rabbit polyclonal antibodies, which selectively recognize a single immunoreactive band $(29 \mathrm{kDa})$ in both crude extracts and purified preparations (not shown).

The polyclonal antibodies produced were purified and fixed to $\mathrm{CN}-\mathrm{Br}$ Sepharose in order to purify the BDH from jerboa liver.

- Purification of membrane-bound BDH from jerboa liver In a typical trial, a total of $5100 \mathrm{mg}$ of protein, corresponding to 5.5 units of $\mathrm{BDH}$, was obtained after solubilization of mitoplast proteins using triton X-100 as nonionic surfactant. After ammonium sulfate fractionation, the concentrated enzyme solution was applied to phenyl-Sepharose HP, Blue Sepharose CL-6B, and immunoaffinity columns. Table 1 summarizes the results of the purification process. A specific activity of $0.030 \mathrm{U} / \mathrm{mg}$ of protein was obtained for the purified enzyme, with a yield of $0.50 \%$ and a purification factor of 37 .

The SDS-PAGE analysis shows that the immunoaffinity step is crucial to eliminate the remaining contaminants of the penultimate fractions. This last purification step shows a single $31 \mathrm{kDa}$ protein (Figure 1), which has been described for other eukaryotic BDH subunits (Figure 1A, lane 5). The $31 \mathrm{kDa}$ jerboa $\mathrm{BDH}$ monomer cross-reacts with the purified antibacterial BDH antibodies (Figure 1B).

\section{- Properties of the purified BDH from jerboa liver}

$\mathrm{BDH}$ kinetic parameters of purified BDH from jerboa liver in liposome-reconstituted phospholipid-enzyme complex were determined. The results obtained show a value of 51 $\mathrm{nmol} / \mathrm{min} / \mathrm{mg}$ for $\mathrm{V}_{\text {max }^{\prime}} 0.45 \mathrm{mM}, 2.1 \mathrm{mM}$, and $1.45 \mathrm{mM}$ for $\mathrm{K}_{\mathrm{M}} \mathrm{NAD}^{+}, \mathrm{K}_{\mathrm{M}} \mathrm{BOH}$ and $\mathrm{K}_{\mathrm{D}} \mathrm{NAD}^{+}$, respectively. The comparison of these values with the parameters of the native $\mathrm{BDH}$ bound to the inner mitochondrial membrane [9] shows small differences in the $K_{M}$ values. This can be explained by the fact that the purified $\mathrm{BDH}$ released from its mitochondrial membrane environment was successfully reconstituted in an active form following addition of mitochondrial phospholipids.

The effect of temperature on the BDH activity was followed. The results obtained show that the optimal temperature for the $\mathrm{BDH}$ activity is $35^{\circ} \mathrm{C}$ for $J$. orientalis [Additional file 2]. This is close to $37^{\circ} \mathrm{C}$ for $\mathrm{BDH}$ from Camelus dromedaries [8] but very different $\left(55^{\circ} \mathrm{C}\right)$ for microbial BDH from Acidovorax [24].

Interestingly, like membrane-bound enzyme, the Arrhenius plots of the reconstituted active purified $\mathrm{BDH}$ show a break at $17^{\circ} \mathrm{C}$ [Additional file 3]. BDH activity dependence on temperature discontinuity was previously found for native $\mathrm{BDH}$ in the heavy mitochondria fraction from Jerboa liver [9]. This property is considered to reflect that $\mathrm{BDH}$ lipids depend on the physical state of the membrane phospholipid bilayer.

The optimal $\mathrm{pH}$ value of $\mathrm{BDH}$ activity is 8 [Additional file 4]. Similar results were found for rat [14], Camelus dromedaries [8], and for the bacteria Acidovorax, Rhodospirillum rubrum and Rhodopseudomonas spheroides [24].

\section{- Nucleotide sequence and analysis of J. orientalis BDH cDNA}

In order to clone the cDNA encoding $\mathrm{BDH}$ from jerboa liver, RT-PCR, primers were selected from two highly conserved BDH regions (LPGKALS and PMDYYWW) from mammalian species since the jerboa genome has not yet

Table I: Purification steps of BDH from jerboa liver

\begin{tabular}{|c|c|c|c|c|c|}
\hline & $\begin{array}{l}\text { Total protein } \\
\text { (mg) }\end{array}$ & $\begin{array}{l}\text { Specific activity } \\
\text { (nmol/min/mg of protein) }\end{array}$ & $\begin{array}{l}\text { Total activity } \\
(\mu \mathrm{mol} / \mathrm{min})\end{array}$ & $\begin{array}{l}\text { Purification factor } \\
\text { (fold) }\end{array}$ & $\begin{array}{l}\text { Yield } \\
\text { (\%) }\end{array}$ \\
\hline Crude extract & 5100 & 1.1 & 5.5 & 1.0 & 100 \\
\hline Ammonium sulphate (30-50\%) & $560 *$ & 8.2 & 4.5 & 7.4 & 82 \\
\hline Phenyl-Sepharose & 350 & 10.4 & 3.6 & 9.4 & 65 \\
\hline Sepharose-Blue & 50 & 17.6 & 0.87 & 16.0 & 16 \\
\hline Immunoaffinity chromatography & 0.75 & 41.3 & 0.030 & 37.5 & 0.50 \\
\hline
\end{tabular}

Typical experiments were reported from three independent trials.

$*$ The ammonium sulphate precipitation step eliminates $91 \%$ of contaminating proteins from Jerboa crude extracts, respectively. These values were calculated from the total protein amount deduced from the amount of BDH (estimated from specific activities after the immunoaffinity chromatography step). 
A

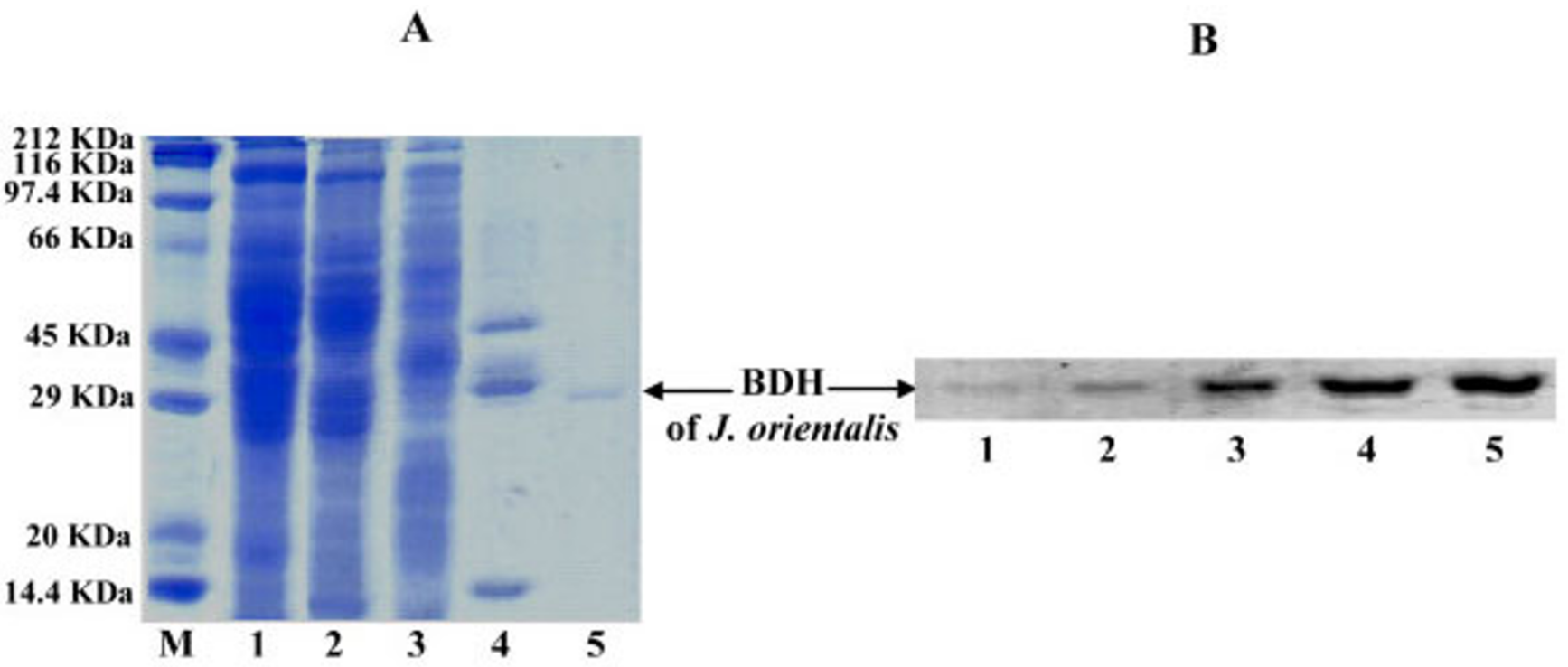

\section{Figure I}

BDH purification steps from jerboa liver. Proteins $(40 \mu \mathrm{g})$ were resolved by SDS-PAGE and stained with Coomassie Brilliant Blue (a) or subjected to Western blot (b) using the purified polyclonal anti-BDH antibodies. Lanes M, I, 2, 3, 4, and 5 represent standard proteins, crude extract, 30-50\% ammonium sulphate fraction, phenyl-Sepharose fraction, affinity chromatography fraction, and immunoaffinity chromatography eluate pool (pure protein preparation). Bound antibody was located by immunoreaction combined with peroxidase conjugated goat anti-rabbit lgG. The arrow (b) indicates the band corresponding to the $\mathrm{BDH}$ subunit.

been sequenced. For the nucleotide sequence, see the section titled "Method" section. The amplification procedure revealed a single cDNA fragment with the expected size (936 pb) [Additional file 5]. The sequenced clone (GenBank accession \# bankit 1072824 EU563473) was aligned and compared with other BDHs, from several species, including the mammalian vertebrate phyla and bacterial species, using the BioEdit program [36]. The highest identity was shown when the sequence was aligned with other mammalian BDH sequences (human, rat and mouse). Indeed, the analysis shown in Figure 2 reveals $79 \%$ identity with rat and mouse, $75 \%$ with human and only $19 \%$ with $P$. aeruginosa. Jerboa $\mathrm{BDH}$ sequence is $92 \%$ complete since amino acids from the C-terminal side are not yet available. The differences in sequences obtained between mammalian and bacterial BDHs can be related to the biochemical properties of both enzymes since mammalian $\mathrm{BDH}$ is membrane-bound and located in mitochondria and bacterial $\mathrm{BDH}$ is soluble and cytosolic. Moreover, the comparison between the two BDH types in terms of cDNA-deduced sequences reveals the major difference in the length of the polypeptide chain: 343 amino acids for the human $\mathrm{BDH}$ vs 256 for Pseudomonas. The longer sequence of the mammalian enzyme is related to the mitochondrial targeting presequence at the $\mathrm{N}$-terminus and to the phospholipid-binding region at the C-terminus (Figure 2) [3,37]. The sequence alignment shows 48 iden- tical amino acids and 42 similar amino acids between the mammalian and the bacterial enzymes.

\section{Discussion and conclusion}

Purifying BDH from Jerboa liver made it possible to overcome its low specific activity in mitochondria for further biochemical characterization of the enzyme.

Previous BDH purification procedures, partial or complete, were successively proposed by different groups in order to improve the purity, the stability, the yield, the time required or simplicity, and to adapt the technique to $\mathrm{BDH}$ from various mammalian sources. The purification procedures were often based on several chromatography steps by combining adsorption, hydrophobic, ionic exchange, or $\mathrm{NAD}^{+}$(or $\mathrm{NAD}^{+}$-related affinity such as the dye affinity matrix or controlled pore glass beads). The published procedures were not convenient to Jerboa liver $\mathrm{BDH}$ purification. For instance, rat liver [31] and bovine heart [27] BDH was not pure and/or contained significant amounts of residual phospholipids. The technique developed in Fleischer's lab $[28,29]$, using controlled pore glass beads (CPG), was adapted for large-scale use and required a huge amount of starting biological material but provided a low yield $(0.02 \%)$. 

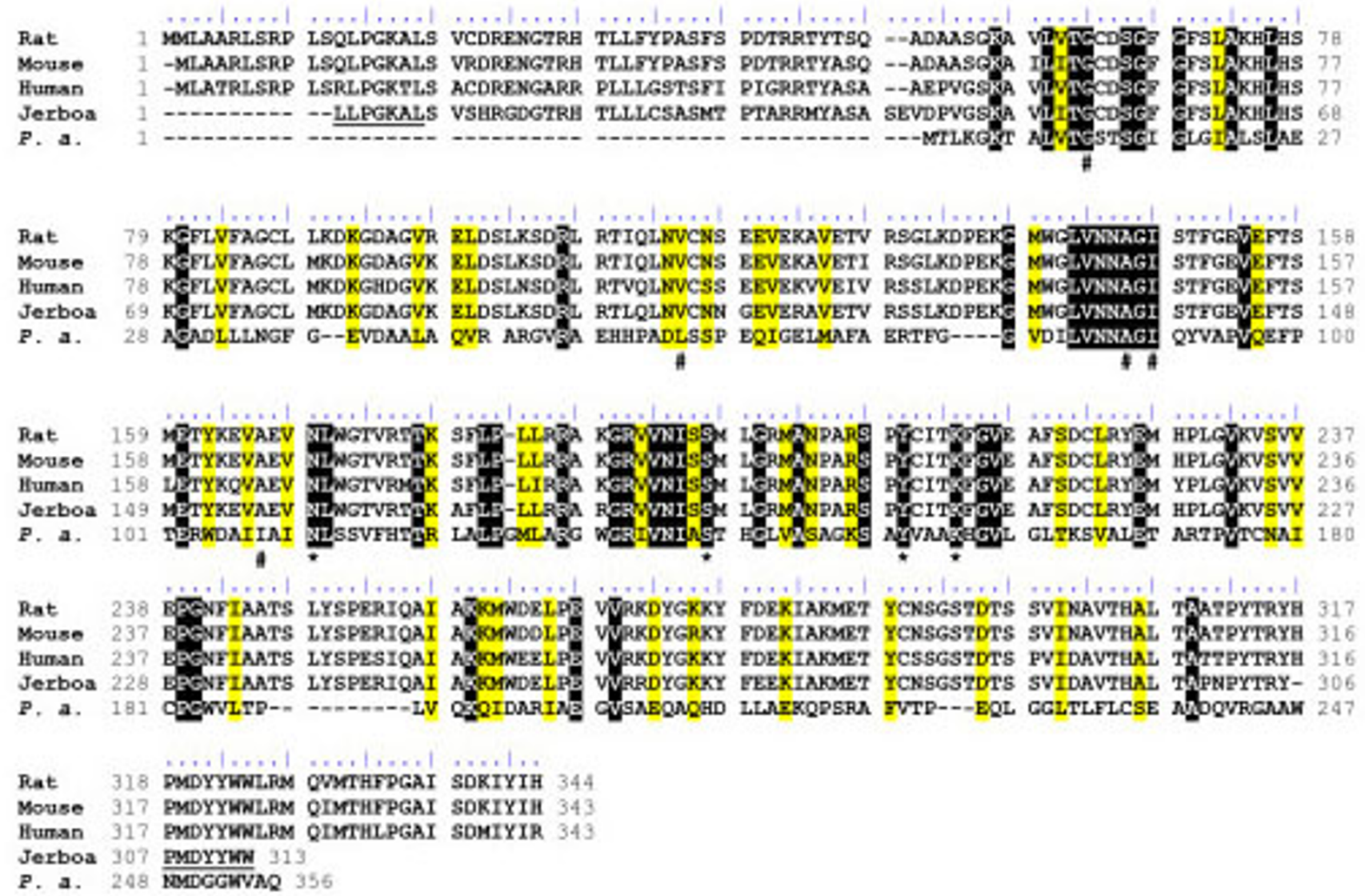

\section{Figure 2}

Alignment of BDH sequences. Alignment of BDH sequences from mammalian species (rat, mouse, human and jerboa) with Pseudomonas aeruginosa (P. a.) was realized using ClustalW (Thompson et al., 1994). Identical and similar residues were shown in black and yellow background respectively. The presumed amino acids sequences corresponding to oligonucleotides used for the PCR amplification of Jerboa BDH cDNA are underlined. According to the identity between Rat, Mouse and Human, they are considered as putative sequences in Jerboa. Amino acids of the catalytic tetrad Asn III, Ser I39, TyrI52 and Lys I56 (P. a. numbering) are marked by a star $\left(^{*}\right)$. These amino acids correspond to Asn I I4, Ser I42, Tyr I 55 and Lys I 59 of the Pseudomonas fragi BDH (Ito et al., 2006). Amino acids participating to the NAD+ binding pocket Gly 12, Leu6I, Ala88, Ile90 and lle I08 (P. a. numbering) are marked by a hash sign (\#). These amino acids correspond to Gly I I, Leu64, Ala9I, lle93 and Leul I 3 of the Pseudomonas fragi BDH (Ito et al., 2006).

Our new procedure was based on the use of polyclonal antibodies raised against BDH from bacterial Pseudomonas aeruginosa. After purification steps using phenyl Sepharose and Blue-Sepharose, Jerboa liver BDH fractions were not pure to homogeneity and required an immunoaffinity column to achieve purification, yielding $0.5 \%$.

The molecular weight of the purified jerboa BDH subunit $(31 \mathrm{kDa})$ shows a similar value to the values given for most of the eukaryotic BDH, e.g., for bovine heart [30], rat liver [33] and human heart [38]. In contrast, BDH from Camelus dromedaries shows a molecular weight of $67 \mathrm{kDa}$ [8], possibly corresponding to an evolutionary duplicated form. The primary sequence of $\mathrm{BDH}$ was previously determined for rat liver [39] and human heart enzyme [38].
The purified jerboa liver $\mathrm{BDH}$ from the $\mathrm{BDH}$-antibody complex is in a readily reactivating form, since the active BDH-mitochondrial phospholipid complex shows similar enzymatic parameters as the native mitochondrially bound BDH, i.e., similar kinetic parameters, a break in the Arrhenius plot, optimum $\mathrm{pH}$, and optimum temperature.

While the sequenced genome of Jaculus orientalis is not available, for the first time a BDH cDNA from jerboa has been cloned and sequenced. From: this and from the purified protein we assume that both correspond to the same molecular entity despite the fact that two kinetically different BDH enzymes were revealed in heavy and light mitochondria fromm jerboa liver [42]. Sequence alignment revealed putative essential amino acids for the 
$\mathrm{NAD}^{+}$interaction. The full identification and the spatial position of $\mathrm{BDH}$ strategic amino acids could not be achieved with a mammalian BDH since no 3D-structure is thus far available despite a number of attempts to obtain crystals (most particularly in studies on the bovine mitochondrial membrane-bound enzyme from S. Fleischer's group, Vanderbilt University, Nashville TN, personal communication). The available structural data are related to the structure of the bacterial BDH of Pseudomonas fragi (the only crystallized and modeled BDH [40]). Based on the Pseudomonas fragi $\mathrm{BDH}$ structure, modeling has revealed that conserved amino acids are closely localized to the $\mathrm{BDH}$ active site[40]. This analysis highlights the importance of these amino acids in the enzyme reaction, especially the strictly conserved tetrad: Asn114, Ser142, Tyr155 and Lys159 (amino acid numbers corresponding to Pseudomonas fragi BDH). In addition, Ito et al. [40] reported that the adenine of $\mathrm{NAD}^{+}$is accommodated in the hydrophobic pocket including Gly11, Leu64, Ala90, Ile93 and Leu113 (Pseudomonas fragi BDH). All these residues were also found in the BDH sequences studied (Figure 2).

This study applied immunoaffinity chromatography to purifying $\mathrm{BDH}$, a membrane-bound and lipid-dependent enzyme. In addition, bacterial $\mathrm{BDH}$ isolation was achieved in a two-step purification procedure. This method also improved the knowledge of a lipid metabolism enzyme in a unique hibernating mammal.

\section{Methods}

- Microorganisms and growth conditions

Bacteria Pseudomonas aeruginosa (Pasteur Institute, Casablanca, Morocco) were grown aerobically at $37^{\circ} \mathrm{C}$ without exceeding the exponential phase in nutrient broth (Topley House, Bury, UK). The exponential phase was determined spectrophotometrically at $600 \mathrm{~nm}$. The culture was inoculated with $1 \%(\mathrm{v} / \mathrm{v})$ overnight preculture in the same medium.

\section{- Buffers}

Buffer A: $50 \mathrm{mM}$ potassium phosphate buffer ( $\mathrm{pH} 7.5$ ) containing $2 \mathrm{mM}$ EDTA and $1 \mathrm{mM}$ DTT.

Buffer B: buffer A containing ammonium sulfate at 50\% saturation.

\section{- Crude extract preparation}

Bacterial culture ( $5 \mathrm{l}$ ) was harvested by centrifugation at $2500 \mathrm{~g}$ for $10 \mathrm{~min}$, washed three times with $50 \mathrm{mM}$ potassium phosphate buffer ( $\mathrm{pH} 7.5$ ), and suspended in the same buffer containing $2 \mathrm{mM}$ EDTA and $1 \mathrm{mM}$ DTT (buffer A). Cells were disrupted at $4{ }^{\circ} \mathrm{C}$ by sonication (30 s, $90 \%$ output, $12 \times$ ) using a Bandelin Sonopuls sonifier. Cellular debris and unbroken cells were removed by cen- trifugation at $2500 \mathrm{~g}$ for $45 \mathrm{~min}$ at $4{ }^{\circ} \mathrm{C}$. The supernatant obtained constituted the crude bacterial extract (soluble protein fraction).

\section{- BDH purification from the bacterium Pseudomonas aeruginosa}

The enzyme was purified from the crude bacterial extract in two steps: ammonium sulfate fractionation and Blue Sepharose CL-6B chromatography. All steps were performed at $4{ }^{\circ} \mathrm{C}$.

\section{Ammonium sulfate fractionation}

The crude extract of $P$. aeruginosa was subjected to protein precipitation in the $27-42 \%$ saturation range of ammonium sulfate at $4{ }^{\circ} \mathrm{C}$. The final pellet was dissolved in a minimal volume of buffer $\mathrm{A}$. The protein solution was dialyzed overnight against $5 \mathrm{l}$ of the same buffer.

\section{Blue Sepharose CL-6B chromatography}

The dialyzed enzyme preparation was applied to a Blue Sepharose CL-6B column equilibrated with two bed volumes of buffer $\mathrm{A}$ at $4{ }^{\circ} \mathrm{C}$. The column was washed with three bed volumes of buffer A. Finally, the enzyme was eluted with buffer A containing $0.1 \mathrm{mM} \mathrm{NAD}^{+}$at a flow rate of $6 \mathrm{ml} / \mathrm{h}$. Active fractions were collected and conserved in $50 \%(\mathrm{v} / \mathrm{v})$ glycerol at $-20^{\circ} \mathrm{C}$ until use.

\section{- Production and purification of the anti-BDH antibodies against soluble BDH from Pseudomonas aeruginosa}

A 1.5-kg New Zealand white rabbit, grown in the university's animal care facilities, was injected with $1 \mathrm{mg}$ of the $\mathrm{BDH}$ purified from P. aeruginosa in aqueous solution ( $\mathrm{v} /$ v) with incomplete Freund's adjuvant. After 21 days, a second dose of $800 \mu \mathrm{g}$ of $\mathrm{BDH}$ was injected. After the 4 th week, a third dose of $500 \mu \mathrm{g}$ was again injected. One week later, the rabbit was anesthetized and $50 \mathrm{ml}$ of blood were collected. The serum was separated after an overnight coagulation at $4^{\circ} \mathrm{C}$ and subsequent centrifugation.

\section{Ammonium sulfate precipitation}

The resulting serum, containing monospecific anti-BDH polyclonal antibodies, was brought to $40 \%$ saturation with solid ammonium sulfate $\left(\left(\mathrm{NH}_{4}\right)_{2} \mathrm{SO}_{4}\right)$, stirred for 1 $\mathrm{h}$, and then centrifuged at $2500 \mathrm{~g}$ for $45 \mathrm{~min}$. Afterwards, the pellet was dissolved in a minimal volume of phosphate buffer saline (PBS), pH 7.4, containing $137 \mathrm{mM}$ $\mathrm{NaCl}, 2.7 \mathrm{mM} \mathrm{KCl}, 1.5 \mathrm{mM} \mathrm{KH} \mathrm{PO}_{4}$, and $4.3 \mathrm{mM}$ $\mathrm{K}_{2} \mathrm{HPO}_{4}$. The antibody solution was dialyzed overnight against $5 \mathrm{l}$ of the same buffer.

\section{lon-exchange chromatography}

The dialyzed antibody preparation was applied at a flow rate of $6 \mathrm{ml} / \mathrm{h}$ to a DEAE-cellulose (Serva, Heidelberg, Germany) column $(3 \times 12 \mathrm{~cm})$ that had been equilibrated with PBS. The column was extensively washed at the same 
flow rate with equilibrating buffer solution. Two-milliliter fractions were collected and those containing the antiBDH antibodies were pooled. Since anti-BDH antibodies are iso-ionic at $\mathrm{pH} 7.4$, they were not retained by the DEAE-cellulose and were generally left with the column's dead volume.

\section{Immunoaffinity chromatography preparation}

Sequence alignments from different species, including $P$. aeruginosa, human, rat, and mouse, revealed that BDHs share an amino acid identity between regions (LVNNAGI, VNI, PG). This property had prompted us to use the antibodies against bacterial BDH to purify the eukaryotic antibody.

We verified the specificity of anti-BDH antibodies by showing that $\mathrm{BDH}$ activities were completely inhibited in both $P$. aeruginosa and jerboa liver using immune serum, which did not inhibit BDH activity in jerboa GAPDH (glyceraldehyde-3-phosphate dehydrogenase) (data not shown). Moreover, preimmune serum had no effect. On the other hand, anti-BDH antibodies reacted with BDHs in western blotting (data not shown).

Immunoaffinity chromatography column $(1 \times 10 \mathrm{~cm})$ was prepared with $\mathrm{CN}-\mathrm{Br}$ Sepharose (Pharmacia) coupled with purified $\mathrm{BDH}$ from $P$. aeruginos a according the supplier procedure. After loading total polyclonal antibodies, the specific anti-BDH antibodies were eluted. and subsequently bound to $\mathrm{CN}-\mathrm{Br}$ Sepharose in order to purify the $\mathrm{BDH}$ from jerboa liver with the same procedure as described above.

\section{Purification of mitochondrial membrane-bound BDH from jerboa liver}

Jerboa housing: adult greater Egyptian jerboas (Jaculus orientalis, Rodentia, Dipodidae) (120-150 g, 4-6 months old) were captured in the area of Engil Aït Lahcen (in the subdesert eastern Morocco highland). They were adapted to laboratory conditions for 3 weeks at a temperature of $22^{\circ} \mathrm{C}$ with a diet of lettuce and rat chow and water ad libitum before killing. The light cycle during the experiment was set to $14 \mathrm{~h}$ of light and $10 \mathrm{~h}$ of darkness. Animal studies were conducted in accordance with the ethical recommendations on Animal Use and Care of the University Hassan II Casablanca.

Remark. We abandoned to purify liver BDH from hibernation Jerboa since hibernation is a complex and very difficult phenomenon to experimentally control and reproduce in a laboratory $[9,21]$. The rate of success is only $20 \%$ survival in contrast with active Jerboa housing.

\section{Liver mitochondria and mitoplast isolation}

The jerboas were decapitated and the livers (75 g total) were rapidly removed for mitochondria purification according to the technique described by Fleischer et al. [41] and as previously used by Mountassif et al. [42]. This method can be used to prepare high-yield mitochondria. The mitoplasts (outer membrane-free mitochondria) were prepared according to Kielley et al. [43]. Briefly, liver mitochondria were swelled in a $20-\mathrm{mM}$ phosphate buffer at $0.5 \mathrm{ml} / \mathrm{mg}$ of protein for $30 \mathrm{~min}$ at $0^{\circ} \mathrm{C}$. The mitoplasts were pelleted by centrifugation at $2500 \mathrm{~g}$ for $30 \mathrm{~min}$.

\section{Membrane solubilization and $\mathrm{BDH}$ release}

The mitoplast fraction was dissolved in an equivalent volume of buffer A containing $0.2 \%$ Triton X-100 and then sonicated. The solubilization was complete after $1 \mathrm{~h}$ incubation on ice. The mixture was then centrifuged at $2500 \mathrm{~g}$ for $1 \mathrm{~h}$ and the supernatant containing the solubilized enzyme was collected.

\section{Ammonium sulfate fractionation}

The supernatant was subjected to protein precipitation in the $30-50 \%$ saturation range of ammonium sulfate. The final pellet was dissolved in a minimal volume of the buffer A containing ammonium sulfate at $50 \%$ saturation.

\section{Phenyl Sepharose chromatography}

The ammonium sulfate fraction was applied at the low flow rate $(12 \mathrm{ml} / \mathrm{h}$ ) to a phenyl Sepharose HP (Pharmacia Biotech) column $(1.6 \times 18 \mathrm{~cm})$ pre-equilibrated with buffer B (buffer A containing ammonium sulfate at 50\% saturation). After flow-thorough washing, the column was subjected to a decreasing linear gradient of ammonium sulfate (from $50 \%$ to $0 \%$ ) in buffer $\mathrm{A}$. The $5-\mathrm{ml}$ fractions of the activity peak were pooled and dialyzed for $2 \mathrm{~h}$ against buffer A after addition of Triton X-100 to the $0.02 \%$ final concentration.

\section{Blue Sepharose CL-6B chromatography}

The dialyzed enzyme preparation was applied to a Blue Sepharose CL-6B column equilibrated with two bed volumes of buffer A. The column was washed with three bed volumes of buffer A. Finally, the enzyme was eluted with buffer A containing $10 \mathrm{mM} \mathrm{NAD}^{+}$at a flow rate of $6 \mathrm{ml} / \mathrm{h}$. Active fractions were collected and pooled.

\section{Immunoaffinity chromatography}

For preparation (see the section titled "Production and purification of the anti-BDH antibodies against soluble BDH from Pseudomonas aeruginosa" above), BDH from jerboa liver was eluted by $5 \mathrm{M} \mathrm{MgCl}_{2}, \mathrm{pH} 7$. Active fractions were selected by measuring the $\mathrm{BDH}$ activity level, collected and dialyzed at $4{ }^{\circ} \mathrm{C}$ for $2 \mathrm{~h}$ against $5 \mathrm{l}$ of buffer $\mathrm{A}$ containing $5 \mathrm{mM} \mathrm{MgCl}_{2}$ and $50 \%$ glycerol. 


\section{Phospholipid extraction and preparation of liposomes}

Phospholipids were extracted from mitoplasts of jerboa liver according to Rouser and Fleischer [44]. One volume of mitoplast preparation was added to chloroform/methanol/0.8\% KCl $(13.3 / 6.7 / 4.2 ; \mathrm{v} / \mathrm{v} / \mathrm{v})$. The mixture was homogenized with an Ultraturrax at $7500 \mathrm{rpm}$ for $3 \mathrm{~min}$. After sedimentation, the organic phase was recovered and methanol/0.8\% KCL/chloroform (48/47/3; v/v/v) was added. The chloroform phase was then concentrated in a rotary evaporator. The phospholipids were dissolved and sonicated in buffer A. The solution obtained was left to decant and the supernatant, which contains small liposomes, was stored at $-20^{\circ} \mathrm{C}$ until use [45]. The amount of phospholipids was determined by measuring the phosphorus concentration according to Chen et al. [46]. Before use, the liposome preparation was quickly sonified.

\section{Protein assay}

The protein content was measured according to the Bradford procedure, using bovine serum albumin (BSA) as standard [47].

\section{$\mathrm{BDH}$ reactivation}

Purified BDH $(10 \mu \mathrm{g})$ was incubated in the buffer containing $6 \mathrm{mM}$ potassium phosphate, $\mathrm{pH} 8,0.5 \mathrm{mM}$ EDTA, 0.3 $\mathrm{mM}$ dithiothreitol in the presence of $0.2 \mu \mathrm{g}$ mitochondrial phospholipid (estimated by lipid phosphorus determination). The mixture was incubated for $10 \mathrm{~min}$ at room temperature and enzymatic activity was then measured.

\section{$\mathrm{BDH}$ activity determination}

As described by El Kebbaj and Latruffe [7], BDH activity was measured at $37^{\circ} \mathrm{C}$ by monitoring NADH production at $340 \mathrm{~nm}\left(\varepsilon=6.22 \times 10^{3} \mathrm{M}^{-1} \mathrm{~cm}^{-1}\right)$ using $100 \mu \mathrm{g}$ of protein homogenate (or $10 \mu \mathrm{g}$ of purified enzyme) in a medium containing $6 \mathrm{mM}$ potassium phosphate, $\mathrm{pH} 8,0.5 \mathrm{mM}$ EDTA, $0.3 \mathrm{mM}$ dithiothreitol, in the presence of $2 \mathrm{mM}$ $\mathrm{NAD}^{+}$(Sigma-Aldrich). The reaction was started by adding DL-3-hydroxybutyrate (Sigma-Aldrich) to the $10-\mathrm{mM}$ final concentration.

\section{- Characterization of jerboa membrane-bound BDH - Denaturing polyacrylamide gel electrophoresis}

Sodium dodecyl sulfate polyacrylamide gel electrophoresis (SDS-PAGE) was performed as described by Laemmli [48] on one-dimensional $12 \%$ polyacrylamide slab gels containing $0.1 \%$ SDS.

\section{- Western blotting}

After SDS-PAGE (12\%) and subsequent transfer in nitrocellulose [49], the proteins $(30 \mu \mathrm{g})$ were exposed to $1 / 100$ dilution of monospecific polyclonal anti-BDH antibody and detected with the secondary antibody (anti-rabbit, IgG peroxidase conjugate) (Promega) diluted to $1 / 2500$.

\section{- BDH enzymatic properties}

Initial velocities were measured at varying $\mathrm{BOH}$ concentrations of (2.5-10 mM) or $\mathrm{NAD}^{+}(0.5-2 \mathrm{mM})$. Michaelis constants $\left(\mathrm{K}_{\mathrm{M}}\right)$, dissociation constants $\left(\mathrm{K}_{\mathrm{D}}\right)$, and maximal velocity of the forward reaction were obtained by mathematical analysis following Cleland [50].

\section{- Determination of optimal pH and temperature- dependent $\mathrm{BDH}$ activity}

The effect of $\mathrm{pH}$ on $\mathrm{BDH}$ activity was studied in a range from $\mathrm{pH} 4$ to 10 using a mixture of different buffers (Tris, Mes, Hepes, potassium phosphate, and sodium acetate).

The temperature effects were characterized by activation and denaturation processes. For activation, the buffered medium containing $6 \mathrm{mM}$ potassium phosphate, $\mathrm{pH} 8$, and $0.5 \mathrm{mM}$ EDTA was incubated for $2 \mathrm{~min}$ at temperatures from 5 to $80^{\circ} \mathrm{C}$. Then, $2 \mathrm{mM}$ of $\mathrm{NAD}^{+}$and $10 \mu \mathrm{g}$ of purified $\mathrm{BDH}$ were added. The reaction was started immediately by the addition of $10 \mathrm{mM}$ of $\mathrm{BOH}$. For denaturation, $10 \mu \mathrm{g}$ of purified $\mathrm{BDH}$ were incubated at temperatures from 5 to $80^{\circ} \mathrm{C}$ for 2 min in medium containing $6 \mathrm{mM}$ potassium phosphate, $\mathrm{pH} 8$, and $0.5 \mathrm{mM}$ EDTA. Then $2 \mathrm{mM}$ of $\mathrm{NAD}^{+}$were added and the enzymatic activity was measured by the later addition of $10 \mathrm{mM}$ of $\mathrm{BOH}$ after $2 \mathrm{~min}$ of incubation at $37^{\circ} \mathrm{C}$.

A BDH Arrhenius plot was obtained by measuring the enzymatic activity at temperatures from 5 to $40^{\circ} \mathrm{C}$ and interpreted as described by Raison [51].

\section{- RNA isolation and RT-PCR}

Total RNAs were obtained from jerboa liver previously frozen in liquid nitrogen and stored at $-80^{\circ} \mathrm{C}$ using Trizol reagent according to the supplier's protocol (Invitrogen).

The primers used were obtained from the alignment between consensus sequences of $\mathrm{BDH}$ from human, rat, and mouse.

First-strand cDNA was produced by reverse transcription (RT) using 200 units of Moloney Murine Leukemia Virus Transcriptase (Promega) in conjunction with $2 \mu \mathrm{g}$ total RNA and the reverse primer; 5'-CCACCAGTAGTAGTCCATG-3' (corresponding to the LPGKALS amino acid sequence starting at amino-acid no. 13 in mouse and human $\mathrm{BDH}$ and at no. 14 in rat $\mathrm{BDH}$ ) in a reaction mixture containing $50 \mathrm{mM}$ Tris- $\mathrm{HCl}$ buffer, $\mathrm{pH} 8.3,75 \mathrm{mM}$ $\mathrm{KCl}, 3 \mathrm{mM} \mathrm{MgCl}_{2}, 10 \mathrm{mM}$ dithiothreitol, and $0.2 \mathrm{mM}$ of each deoxynucleoside triphosphate for $1 \mathrm{~h}$ at $42^{\circ} \mathrm{C}$. An aliquot from this template ( $1 / 10$ of the reaction) was used in a subsequent polymerase chain reaction (PCR) using $1.25 \mathrm{U}$ of GoTaq DNA polymerase (Promega), $0.04 \mu \mathrm{M}$ of reverse and forward primer (5'-CTCCCAGGAAAA(A/ $\mathrm{G}) \mathrm{C}(\mathrm{C} / \mathrm{T}) \mathrm{CTAAGTG}-3^{\prime}$ ) (corresponding to the 
PMDYYWW amino acid sequence starting at amino acid no. 223 in mouse and human BDH and at no. 224 in rat BDH). PCR was performed for 35 cycles in the following conditions; $92^{\circ} \mathrm{C}$ for $30 \mathrm{~s}, 55^{\circ} \mathrm{C}$ for $30 \mathrm{~s}$, and $72^{\circ} \mathrm{C}$ for 1 $\min 30 \mathrm{~s}$.

\section{- Cloning and sequencing of the BDH clone from J. orientalis}

The PCR product was purified using QIAEX II Kit (Qiagen) and subcloned into the pGEM-T vector system (Promega), and the nucleotide sequence was determined on both strands using universal primers T7 and SP6 (MWG Biotech, Germany).

The sequence obtained and other sequences were compared using the BioEdit program [36] and ClustalW [52].

\section{Abbreviations}

BDH: D-3-hydroxybutyrate dehydrogenase; DL-BOH: DL3-hydroxybutyrate; BSA: bovine serum albumin; EDTA: ethylene-diamine tetra-acetic acid; Hepes: 4-(2-hydroxyethyl)-1-piperazine ethane sulfonic acid; Mes: 4-N-morpholinoethanesulfonic acid; $\mathrm{NAD}(\mathrm{H})$ : nicotinamide adenine dinucleotide oxidized/(reduced) forms; SDSPAGE: sodium dodecyl sulfate-polyacrylamide gel electrophoresis; TMB: tetramethyl benzidine; Tris: trihydroxymethyl-aminomethane.

\section{Authors 'contributions}

DM had the original idea to purify BDH by immunoaffinity and conducted the purification and the enzyme characterization. PA managed the biochemical modeling and interpretation. ZEK contributed to Western blotting procedures. AM helped in the antibody preparation. MCM gave advise on the development of the paper and provided financial support. NL managed the work and improved the manuscript. MSEK, as general manager, assisted in bringing the project to term.

\section{Additional material}

\section{Additional file 1}

Determination of $\mathrm{BDH}$ molecular weight in denaturing conditions of electrophoresis

Click here for file

[http://www.biomedcentral.com/content/supplementary/1471-

2091-9-26-S1.eps]

\section{Additional file 2}

Influence of temperature in the activation-denaturation processes of purified BDH from Jerboa

Click here for file

[http://www.biomedcentral.com/content/supplementary/14712091-9-26-S2.eps]

\section{Additional file 3}

Arrhenius plot of Jerboa BDH activation catalytic process Click here for file

[http://www.biomedcentral.com/content/supplementary/14712091-9-26-S3.eps]

\section{Additional file 4}

pH dependency of Jerboa BDH activity

Click here for file

[http://www.biomedcentral.com/content/supplementary/1471-

2091-9-26-S4.eps]

\section{Additional file 5}

BDH cDNA clone amplification by RT-PCR

Click here for file

[http://www.biomedcentral.com/content/supplementary/1471-

2091-9-26-S5.eps]

\section{Acknowledgements}

This work was supported by the Regional Council of Burgundy and IFR No. 100, the Programme Thématique d'Appui à la Recherche ScientifiqueMorocco, Biologie no. 134, and the Action intégrée franco-marocaine MA/ 05/I 34. We thank Pr Mostapha Kabine (Univ. Hassan II, Casablanca) for helping to catch wild Jerboa and for his usefull advises due to his long experience with this animal, Mrs Nathalie Bancod (Univ. Burgundy, Dijon) for text processing and Mrs Linda Northrup (English solutions) for English improvement.

\section{References}

I. Latruffe N, Gaudemer Y: Properties and Kinetic mechanism of D-3-hydroxybutyrate dehydrogenase from rat liver submitochondrial particles, Comparatives effects of different thiol reagents. Biochimie 1974, 56:435-444.

2. Gaudemer $Y$, Latruffe N: Evidence for penetrant and non-penetrant thiol reagents and their use in the location of rat liver mitochondrial D-3-hydroxybutyrate dehydrogenase. FEBS Lett 1975, 54:30-34.

3. Berrez JM, Latruffe N, Gaudemer Y: Limited proteolysis of $\mathbf{D}$ beta-hydroxybutyrate dehydrogenase: relationships between phospholipid-protein interactions and catalytical activity. Biochem Int 1984, 8:697-706.

4. Kante A, Latruffe N, Duroc R, Nelson BD: Import and processing of D- $\beta$-hydroxybutyrate dehydrogenase larger precursor into mitochondria after in vitro translation of rat liver free polysomes. Life Sci Adv Biochem 1987, 6: I I I-I23.

5. Kante A, Malki MC, Coquard C, Latruffe N: Metabolic control of the expression of mitochondrial D-3-hydroxybutyrate dehydrogenase, a ketone body converting enzyme. Biochim Biophys Acta 1990, 1033:291-307.

6. Adami P, Nasser B, Latruffe N: Interaction of the mitochondrial rat liver D-3-hydroxybutyrate dehydrogenase with glass beards during adsorption chromatography, relationships with the activation of the enzyme by phospholipids. J Chromatogr 1991, 539:279-287.

7. El Kebbaj MS, Latruffe N: Alkylation at the active site of the D3-hydroxybutyrate dehydrogenase a membrane phospholipid-dependent enzyme, by 3-chloroacetyl pyridine adenine dinucleotide (3-CAPAD). Biochimie 1997, 79:37-42.

8. Nasser B, El Kebbaj MS, Cottin P, Latruffe N: Purification and characterization of the D-beta-hydroxybutyrate dehydrogenase from dromedary liver mitochondria. Comp Biochem Physiol Biochem 2002, Part B 13 I:9-18.

9. Mountassif D, Kabine M, Latruffe N, El Kebbaj MS: Prehibernation and hibernation effects on the D-3-hydroxybutyrate dehydrogenase of the heavy and light mitochondria from liver jer- 
boa (Jaculus orientalis) and related metabolism. Biochimie 2007, 89:1019-1028.

10. Wise JB, Lehninger AL: The stability of mitochondrial D-3hydroxybutyric dehydrogenase and its relationships to the respiratory chain. J Biol Chem 1962, 237:1363-1670.

II. Nielsen NC, Zahler WL, Fleischer S: Mitochondrial D-3-hydroxybutyrate dehydrogenase: IV. Kinetic analysis of reaction mechanism. J Biol Chem 1973, 248:2556-2562.

12. McIntyre JO, Bock HGO, Fleischer S: The orientation of D-3hydroxybutyrate dehydrogenase in the mitochondrial inner membrane. Biochim Biophys Acta 1978, 5 I 3:255-267.

13. Mihara K, Omura T, Harano T, Brenner S, Fleischer S, Rajagopalan KV, Blobel G: Rat liver L-glutamate dehydrogenase, malate dehydrogenase, D-beta-hydroxybutyrate dehydrogenase, and sulfite oxidase are each synthesized as larger precursors by cytoplasmic free polysomes. J Biol Chem 1982, 257:3355-8.

14. Sekuzu I, Jurtshuk PJr, Green De: On the isolation and properties of the D-3-hydroxybutyric dehydrogenase of beef heart mitochondria. Biochem Biophys Res Commun 1961, 6:71-5.

15. Gazzoti P, Bock HGO, Fleischer S: Role of lecithin in D-3 hydroxybutyrate dehydrogenase function. Biochem Biophys Res Commun 1964, 58:309-3।5.

16. Sandermann $\mathrm{H}$ Jr. Mclntyre JO, Fleischer S: Site-site interaction in the phospholipid activation of D-beta-hydroxybutyrate dehydrogenase. J Biol Chem 1986, 26 I:620I-6208.

17. Rudy B, Dubois H, Mink R, Trommer WE, McIntyre JO, Fleischer S: Coenzyme binding by 3-hydroxybutyrate dehydrogenase, a lipid-requiring enzyme: lecithin acts as an allosteric modulator to enhance the affinity for coenzyme. Biochemistry 1989, 28:5354-5366

18. Williamson DH, Bates HN, Page MA, Krebs HA: Activities of enzymes involved in acetoacetate utilization in adult mammalian tissues. Biochem J 1997, I 2 I:4I-47.

19. Dawes EA, Senior PJ: The role and regulation of energy reserve polymers in microorganisms. Adv Microb Physiol 1973, 10:135-266.

20. Preuveneers MJ, Peacock D, Crook EM, Clark JB, Brocklehurst R: D3-hydroxybutyrate dehydrogenase from Rhodopseudomonas spheroides. Kinetics of radioisotope redistribution at chemical equilibrium catalysed by the enzyme in solutions. Biochem J 1973, 133:133-157.

21. Kabine M, El Kebbaj MS, Hafiani A, Latruffe N, Cherkaoui-Malki M: Hibernation impact on the catalytic activities of the mitochondrial $D$ - $\beta$-hydroxybutyrate dehydrogenase in liver and brain tissues of jerboa (Jaculus orientalis). BMC 2003:4-II.

22. El Hilali M, Veillat JP: Jaculus orientalis: A true Hibernator. Mammalia 1979, 39:40I-404.

23. Bergmeyer HU, Gawehn K, Klotzsch $\mathrm{H}$, Krebs HA, Williamson DH Purification and properties of crystalline 3-hydroxybutyrate dehydrogenase from Rhodopseudomonas spheroides. Biochem | 1967, I02:423-43|.

24. Takanashi M, Shibahara T, Shiraki M, Saito T: Biochemical and Genetic Characterization of a D-3-Hydroxybutyrate dehydrogenase from Acidovorax sp. Strain SAI. J Biosc Bioeng 2004, I:78-8I.

25. Nielsen NC, Fleischer S: Mitochondrial D-3-hydroxybutyrate dehydrogenase. 3. Isolation and characterization. J Biol Chem 1973, 248:2549-2555

26. Menzel HM, Hammes GG: Purification and characterization of a lecithin-D-hydroxybutyrate dehydrogenase complex. J Biol Chem 1973, 248:4885-4889.

27. Grover AK, Hammes GG: Affinity chromatography of betahydroxybutyrate dehydrogenase on NAD+ and hydrophobic chain derivatives of sepharose. BBA 1974, 556:309-3/8.

28. Bock H, Fleischer S: Preparation of a homogeneous soluble Dbeta-hydroxybutyrate apodehydrogenase from mitochondria. J Biol Che 1975, 250:5774-576 .

29. Bock HG, Skene P, Fleischer S, Cassidy P, Harshman S: Protein purification: adsorption chromatography on controlled pore glass with the use of chaotropic buffers. Sciences 1976, 291:380-383.

30. Burnett BK, Khorana HG: A rapid and efficient procedure for the purification of mitochondrial D-3-hydroxybutyrate dehydrogenase. Biochim Biophys Acta 1985, 81 5:5 I-56.
31. Gotterer GS: Rat liver D-beta-hydroxybutyrate dehydrogenase. I. Partial purification and general properties. Biochemistry 1967, 6:2139-2I52.

32. Vidal JC: Purification of apo-3-D-hydroxybutyrate dehydrogenase from rat liver mitochondria. Mol Cell Biochem 1977, 16:153-169.

33. Mclntyre JO, Latruffe N, Brenner S, Fleischer S: Comparison of 3 hydroxybutyrate dehydrogenase from bovine heart and rat liver mitochondria. Arch 1988, 262:85-98.

34. Zhang WW, Redman K, Churchill S, Churchill P: Comparison of Dbeta-hydroxybutyrate dehydrogenase from rat liver and brain mitochondria. Biochem Cell Biology 1990, 68:980-983.

35. Langston HP, Jones L, Churchill S, Churchill PF: Purification and characterization of a (R)-3-hydroxybutyrate dehydrogenase deletion mutant. Evidence for C-terminal involvement in enzyme activation by lecithin. $A B B$ 1996, 327:45-52.

36. Hall TA: BioEdit: a user-friendly biological sequence alignment editor and analysis program for Windows 95/98/NT. Nucl Acids Symp Ser 1999, 41:95-98.

37. Maurer A, McIntyre JO, Churchill S, Fleischer S: Phospholipid protection against proteolysis of $D$-beta-hydroxybutyrate dehydrogenase, a lecithin-requiring enzyme. J Biol Chem 1985 , 260:166I-1669.

38. Marks AR, McIntyre JO, Duncan TM, Erdjument-Bromage H, Tempst $P$, Fleischer S: Molecular cloning and characterization of (R)-3hydroxybutyrate dehydrogenase from human heart. I Biol Chem 1992, 267:15459-15463.

39. Churchill P, Hempel J, Romovacek H, Zhang WW, Brennan M, Churchill S: Primary structure of rat liver D-beta-hydroxybutyrate dehydrogenase from CDNA and protein analyses: a short-chain alcohol dehydrogenase. Biochemistry 1992 3 I:3793-3799.

40. Ito K, Nakajima Y, Ichihara E, Ogawa K, Katayama N, Nakashima K, Yoshimoto T: D-3-hydroxybutyrate dehydrogenase from Pseudomonas fragi: Molecular cloning of the enzyme gene and crystal structure of the enzyme. J Mol Biol 2005, 355:722-733.

4I. Fleischer S, Mc Intyre JO, Vidal JC: Large-scale preparation of rat liver mitochondria in high yield. Meth Enzymol 1979, 55:32-39.

42. Mountassif D, Kabine M, Latruffe N, EL Kebbaj MSE: Characterization of two D-3-hydroxybutyrate dehydrogenase populations in heavy and light mitochondria from jerboa (Jaculus orientalis) liver. Comp Biochem Physiol B 2006, | 43:285-93.

43. Kielley WW, Bronk JR: Oxidative phosphorylation in mitochondrial fragments obtained by sonic vibration. J Biol Chem 1958 , 230:52I-533.

44. Rouser G, Fleischer S: Isolation, Characterization and determination of polar lipids of mitochondria. Meths Enzymol 1967, 10:385-406.

45. Fleischer $\mathrm{S}$, Klouwen $\mathrm{H}$ : The role of soluble lipid in mitochondrial enzyme system. Biochem Biophys Res Commun 1961, 5:378-393.

46. Chen PS, Torribara T, Warner H: Microdetermination of phosphorus. Anal Chem 1956, 28: 1756-1758.

47. Bradford $M$ : A rapid and sensitive method for the quantitation of microgram quantities of protein utilizing the principle of protein dye binding. Anal Biochem 1976, 72:248-254.

48. Laemmli UK: Cleavage of structural proteins during the assembly of the head of bacteriophage T4. Nature 1970 , 227(5259):660-5.

49. Towbin H, Stahelin T, Gordon J: Electrophoretic transfer of proteins from polyacrylamide gels to nitrocel procedure and applications. Biotechnology 1992, 24:| 145-149.

50. Cleland WW: The Kinetics of enzymes catalysed reaction with two or more substrates or products, Nomenclature and rate equations. Biochim Biophys Acta 1963, 67:104-137.

5I. Raison JK: The influence of temperature-induced phase changes on the kinetics of respiratory and other membraneassociated enzyme systems. J Bioenerg 1973, 4(I):285-309.

52. Thompson JD, Higgins DG, Gibson T]: CLUSTAL W: Improving the sensitivity of progressive multiple sequence alignment through sequence weighting, positions-specific gap penalties and weight matrix choice. Nucleic Acids Res 1994, 22:4673-4680. 